\title{
The effects of inquiry-based experiment-integrated science games among secondary school students
}

\author{
Eylem Bayir', Sefanur Evmez ${ }^{2}$ \\ ${ }^{1}$ Department of Science Education, Trakya University, Turkey \\ ${ }^{2}$ Selahaddin Eyyubi Secondary School, Turkey
}

\begin{tabular}{l}
\hline Article Info \\
\hline Article history: \\
Received Jun 9, 2019 \\
Revised Jul 29, 2019 \\
Accepted Aug 24, 2019 \\
\hline
\end{tabular}

Keywords:

Educational games

Electricity

Light and sound

Scientific process skills

Student achievement

\begin{abstract}
This study aimed to investigate how inquiry-based experiment-integrated science games affect the achievement and scientific process skills of 5th grade students. The topics of "Light and Sound" and "Electricity in Our Lives" were selected for the experiment. Two groups totaling 41 students participated. The research method consisted of a quasi-experimental design utilizing an experimental and control group. While 21 students in the experimental group played inquiry-based experiment-integrated science games developed by the researchers, no educational game was included in the lessons of the control group of 20 students. "Light and Sound Achievement Test", "Electricity Achievement Test" and "Science Process Assessment" were applied to both groups in the form of a pre- and post-test. To analyze the data, independent t-test was used. Students in the experimental group were more successful than the control group in their scores for both achievement and scientific process skills. It can be inferred from the results that students develop better achievement and scientific process skills by playing science games. It is recommended that such games should be integrated into the science classroom.
\end{abstract}

Copyright (c) 2019 Institute of Advanced Engineering and Science. All rights reserved.

\section{Corresponding Author:}

Eylem Bayir,

Department of Science Education,

Trakya University,

Kosova Campus, Aysekadin, 22800 Edirne, Turkey.

E-mail: eylembudak76@gmail.com

\section{INTRODUCTION}

Playing games is a phenomenon inherent in every child and is an indispensable part of children's lives. Games provide a natural learning environment for children. Considering that the educational process and curriculum programs should be organized on the basis of a child's nature, impulses, desires and feelings [1], the use of games in class makes the lessons both interesting and enjoyable for students and facilitates their learning. The type of game used in the educational process is termed "educational game". Such games should be administered so as to encourage the students to be active in the class and include achievement in the courses. Educational games should also be stimulating and entertaining for students, giving them the opportunity to think, providing reinforcement for the learners, and helping to correct erroneous learning [2]. Studies have shown that the employment of games in education contribute to student development in many ways. If educational games are used consciously in lessons, they contribute to the motor development, cognitive, affective, mental and social development of the learners [3-15]. In view of this potential, the teaching of science by means of carefully-formulated games should be given more prominence. Playing games that are educational and competitive in science classes provides an interesting, alternative method. Science-based games are effective learning tools to help students understand scientific topics, ensure that they are active during lessons, incorporate fun while learning, and to encourage the students to use the 
knowledge they have learned in new situations. For these reasons, there is increased interest in devising and using a variety of educational games in science teaching [16-19].

A review of the literature revealed that games developed in science education are mostly aimed at teaching scientific content, and scientific processes are not included. However, it is important that children also learn to adopt scientific process skills, i.e. ways of acquiring knowledge, because they provide many benefits for the young learners. Scientific process skills are mental and physical skills used to gather information, organize knowledge in various forms, explain phenomena and solve problems [20]. These skills are fundamental to establishing good habits in science and involve students being active and responsible for their learning, which increases the permanence of learning and attaining sound research methods. These skills are also life skills. However, science education must also incorporate scientific process skills as they are necessary for everyone in order to become science-literate, not only students who will become scientists in the future $[21,22]$. The inclusion of inquiry-based experiments that have the potential to develop scientific process skills via educational games makes the students' learning of science more enjoyable and easier; at the same time, they acquire scientific learning and gain scientific skills. From this point of view, inquiry-based experiment-integrated science games on the subjects of light, sound and electricity were developed in this study, and the effects of the games on 5th grade students in terms of advancing their achievement and scientific process skills were investigated.

\section{RESEARCH METHOD}

The quasi-experimental design was used in this study, where the dependent variables are measured once before the treatment is implemented and once after it is implemented. In order to determine the influence of inquiry-based experiment-integrated games on the achievement and scientific process skills of 5 th grade students, both the experimental and control groups were measured before (pre-test) and after (posttest) the experimental group was exposed to the treatment.

\subsection{Research sample}

Forty-one fifth grade students from a secondary school took part in this study which was carried out with two groups, namely, experimental and control. There were 21 students in the experimental group and the control group comprised 20 students. Students were assigned in random order to either of the two groups.

\subsection{Research data collection tools}

For evaluation, the "Light and Sound Achievement Test", "Electricity Achievement Test" and "Science Process Assessment" were used as the data collection tools.

\subsection{1. $\quad$ Light and sound achievement test}

The "Light and Sound Achievement Test" used to determine the students' achievement in subjects of light and sound was adapted selectively from that developed by [23] and comprised 24 questions in the multiple-choice format. The opinions of two experts were taken for validity of the test and any necessary alterations were made. The KR-20 reliability value of the measurement tool was found to be 0.92 by [23]. In this study, it was calculated as 0.87 .

\subsubsection{Electricity achievement test}

The "Electricity Achievement Test" used to determine the students' achievement on the subject of electricity was formulated by the selection of appropriate questions from the test developed by [24]. The test consisted of 13 multiple-choice questions. Two expert opinions were taken for validation of the test and the necessary arrangements were made. The KR-20 reliability value of the measurement tool was found to be 0.89 by [24] and in this study was calculated to be 0.82 .

\subsubsection{Science process assessment}

After being translated into Turkish by [25], the "Science Process Assessment" developed by Kathleen A. Smith and Paul W. Welliver was applied in this study to evaluate the progress of the students in acquiring scientific process skills. Consisting of 40 multiple-choice questions, the reliability coefficient of the test was calculated as 0.81 by [25]. In this study, it was calculated as 0.91 .

\subsection{Implementation}

The "Light and Sound Achievement Test", "Electricity Achievement Test" and "Science Process Assessment" were applied as a pre-test before the implementation. After learning about the subjects of light, sound and electricity, the experimental group played games for four hours for each topic. In the games, 
inquiry-based experimental tasks that children had to complete in order to be able to move forward on the game tables, and thought-provoking questions, were given. The games were arranged with 4 players and 1 referee, each student taking turns to be the referee. The result of the game was determined after 5 rounds. The referee directed the game using the answer keys prepared separately for each player. In the control group, no game was performed after the subjects were taught. The "Light and Sound Achievement Test", "Electricity Achievement Test" and "Science Process Assessment" were applied as a post-test after the implementation.

\section{RESULTS AND DISCUSSION}

The results obtained from analysis of the data that were collected are presented here under two subtitles, "Results and Analysis for Achievement" and "Results and Analysis for Scientific Process Skills".

\subsection{Results and analysis for achievement}

In order to assess how much the students learned from their experience of playing inquiry-based and experiment-integrated science games on the subjects of "Light and Sound" and "Electricity", independent ttest was initially applied to the results of the pre-test for the "Light and Sound Achievement Test" and "Electricity Achievement Test". The findings are given in Table 1.

According to the findings, no statistically significant difference was found when comparing the average pre-test scores obtained from the "Light and Sound Achievement Test" $[\mathrm{t}(39)=-1.03 ; \mathrm{p}>.05)]$ and "Electricity Achievement Test" [t(39)=0.347; $>>$.05)]. It can be said that the students in the two groups are equivalent in respect of their knowledge level in both subjects. Therefore, the independent t-test was also carried out on the data obtained from the post-test scores for the "Light and Sound Achievement Test" and "Electricity Achievement Test". The findings are presented in Table 2.

Table 1. Independent t-Test results for achievement pre-tests

\begin{tabular}{cccccccc}
\hline & Group & $\mathrm{N}$ & Mean & Std. Deviation & Df & $\mathrm{t}$ & $\mathrm{p}$ \\
\hline Light and Sound & Experimental Group & 21 & 8.00 & 3.15 & 39 & -1.03 & .308 \\
Achievement Test & Control Group & 20 & 8.90 & 2.36 & & \multirow{2}{*}{0.347} \\
Electricity Achievement & Experimental Group & 21 & 3.33 & 2.41 & \multirow{2}{*}{39} & \multirow{2}{*}{0.30} \\
Test & Control Group & 20 & 3.10 & 1.83 & & & \\
\hline
\end{tabular}

Table 2. Independent t-Test results for achievement post-tests

\begin{tabular}{|c|c|c|c|c|c|c|c|}
\hline & Group & $\mathrm{N}$ & Mean & Std. Deviation & Df & $\mathrm{t}$ & $\mathrm{p}$ \\
\hline Light and Sound & Experimental Group & 21 & 16.47 & 2.46 & & & \\
\hline Achievement Test & Control Group & 20 & 12.10 & 2.94 & 39 & 5.18 & .000 \\
\hline Electricity Achievement & Experimental Group & 21 & 10.48 & 1.12 & 30 & & \\
\hline Test & Control Group & 20 & 7.85 & 1.98 & 39 & 5.25 & .000 \\
\hline
\end{tabular}

In regard to the findings in Table 2, a difference is seen in the mean scores between the post-test for the "Light and Sound Achievement Test" $[\mathrm{t}(39)=2.71 ; \mathrm{p}<.05)]$ and "Electrical Achievement Test" $[\mathrm{t}(39)=2.90 ; \mathrm{p}<.05)]$ showing that the experimental group was more successful. This indicates significantly higher academic achievement when inquiry-based experiment-integrated science games are used in lessons on light, sound and electricity.

\subsection{Results and analysis for scientific process skills}

To examine the impact on students' scientific process skills of classroom games that involve making inquiries and carrying out experiments, we applied an independent samples t-test to the findings obtained from the "Science Process Assessment" pre-test (Table 3).

Table 3. Independent t-Test results for pre-tests of scientific process skills

\begin{tabular}{ccccccc}
\hline Group & $\mathrm{N}$ & Mean & Std. Deviation & Df & $\mathrm{t}$ & $\mathrm{p}$ \\
\hline Experimental Group & 21 & 15.86 & 5.06 & \multirow{2}{*}{39} & \multirow{2}{*}{-1.81} & \multirow{2}{*}{079} \\
Control Group & 20 & 18.60 & 4.64 & & & \\
\hline
\end{tabular}

When the results in Table 3 are examined, no great difference between groups is observed regarding between the pre-test scores in "Science Process Assessment" $[\mathrm{t}(39)=-2.36 ; \mathrm{p}>.05)]$. Based on these findings, 
it can be said that the scientific process skills of students in both the experimental and control groups were similar. Hence, the post-test scores for "Science Process Assessment" were also subjected to the independent t-test. Table 4 shows the results obtained from the data.

Table 4. Independent t-Test results for post-tests of scientific process skills

\begin{tabular}{ccccccc}
\hline Group & $\mathrm{N}$ & Mean & Std. Deviation & Df & t & $\mathrm{p}$ \\
\hline Experimental Group & 21 & 27.24 & 4.93 & \multirow{2}{*}{39} & 4.8 & \multirow{2}{*}{000} \\
Control Group & 20 & 19.75 & 4.96 & & 5 & \\
\hline
\end{tabular}

That there is a significant difference between the means of the post-test scores $[\mathrm{t}(39)=4.85 ; \mathrm{p}<.05)]$ for "Science Process Assessment" is clear from Table 4. The higher result for the experimental group illustrates how the use of inquiry-based experiment-integrated science games in the teaching of light, sound and electricity led to a significant increase in students' development of their scientific process skills.

This study investigated the impact of inquiry-based experiment-integrated science games on the achievement of 5th grade students. A notable variation was found regarding achievement according to the results of the experimental and control groups. The experimental group performed better in the classroom when learning about light, sound and electricity. Thus, inquiry-based experiment-integrated science games are more effective in increasing the achievement of students. It is possible to state this because the games give the students hands-on experience with these subjects and they encourage students to be physically and mentally active.

In the games that were prepared, task cards directing the students to conduct experiments and answer questions provoking thoughtful and conceptual associations can be said to be important tools in achieving this success. The procedure involves referees who direct the game by using answer keys which are prepared individually for each player; therefore, the players receive instant feedback, which in turn facilitates learning. That students want to play the game over and over again shows that they have a lot of fun during the game and their motivation to play is high. It can be said that this facilitates learning.

The results of this study show that inquiry-based experiment-integrated science games are effective in increasing the achievement of young learners. These results are analogous to similar results in the literature [8, 12, 15, 26-29]. Although studies in the literature do not include inquiry-based experiments regarding content, this study is similar in terms of having scientific content. In one study, Dumlu Güler incorporated educational games in teaching of the topic "Cells and Organelles" and concluded that educational games were more effective in increasing academic achievement in teaching science and technology than traditional teaching [26] methods. Similarly, Al-Tarawneh found that educational games positively contributed to students' understanding of the concepts used in science [12]. Chang et al. concluded that the "Elemental Knock-Out" game developed for undergraduate students was effective in learning the names, symbols and atomic numbers in the periodic table [27]. Franco-Mariscal et al. found that the experimental group students working with games obtained statistically better achievement results compared to control group students instructed according to customary methods [8]. Gürpınar concluded that the academic success of students learning about the "Systems in Our Body" was the result of educational gamesupported teaching practice [28]. Öztürk Coşan found that educational games increase students' success as a result of his work on various biology games [29]. Erlina and Dylan developed a playful activity supported by simple molecular models by addressing the conceptual challenges that students may face when using the VSEPR (valence shell electron pair repulsion) model [15]. The overall conclusion of the study was that activity cards and molecular models being present in class led to deeper comprehension.

The second objective of this study was to examine how the scientific process skills of 5th grade students were influenced by participating in inquiry-based experiment-integrated science games in the classroom. A large difference was found in the acquired skills of the experimental and control groups, with the experimental group gaining the most. Thus we can conclude that the playing of inquiry-based and experiment-integrated science games is effective in developing these skills. In this study, the task cards in the games developed for the three subjects on the science curriculum require students to conduct inquiry-based experiments. In this context, many scientific process skills are included such as making observations, predicting, hypothesizing, classifying, determining variables, conducting experiments, recording data, and making inferences. It is possible to say that the students' frequent use of these skills during play contributed to their development of scientific process skills. Although there is no study in the literature that integrates inquiry-based activities with educational games, the current study's results correlate with those of studies proposing that inquiry-based activities develop students' scientific process skills [30-33]. The integration of inquiry-based experiments in science games has great importance in terms of ensuring the development of such skills among children, while at the same time providing enjoyable activities for children to learn about science. In this sense, our study will make a considerable contribution to the related literature.

The effects of inquiry-based experiment-integrated science games on secondary ... (Eylem Bayir) 


\section{CONCLUSION}

We should include educational science games in science lessons by integrating inquiry-based experiments. If we use such inquiry-based experiment-integrated games in science lessons, it will increase the achievement of students and develop their scientific process skills while they acquire knowledge in an enjoyable way.

\section{ACKNOWLEDGEMENTS}

We would like to express our gratitude for the support of the Scientific Research Projects Coordination Unit, Trakya University, Turkey (Project No. 2017/63). Mr. Graham H. Lee is also thanked for checking the English of the manuscript.

\section{REFERENCES}

[1] Obut, S., "Elementary 7th grade, teaching the structure of atom and periodic table in the journey unit to the internal structure of matter with educational games in computer environment and developing a model for it (in Turkey)," Master Thesis, Celal Bayar Üniversitesi Fen Bilimleri Enstitüsü, Manisa, 2005.

[2] Zengin, H. K., "Educational games and the use of religious culture and ethics in primary education (in Turkey)," Master Thesis, Ankara Üniversitesi/Sosyal Bilimler Enstitüsü, Ankara, 2002.

[3] Onay, C., "Game education according to multiple intelligence theory (in Turkey)," Ankara: Nobel, 2006.

[4] Çavuş, R., Kulak, B., Berk, H., \& Öztuna Kaplan, A., "Game activities in science and technology teaching and adaptation of games in daily life (in Turkey)," IGEDER Fen ve Teknoloji Öğretmenleri Zirvesi, İstanbul, 2011.

[5] Kayabaşı, Y. \& Akbaş, C., "The effect of teaching with educational games on student achievement in science course, (in Turkey)," Ĕ̆itim ve Ögretim Araştırmaları Dergisi, vol. 6(2), pp. 181-193, 2017.

[6] Bayır, E., "Developing and playing chemistry games to learn about elements, compounds, and the periodic table: Elemental Periodica, Compoundica, and Groupica," Journal of Chemical Education, February, vol. 91(4), pp. 531-535, 2014.

[7] Kırıkkaya, E. B., İşeri, Ş. \& Vurkaya, G., "A board game about space and solar system for prımary school students," The Turkish Online Journal of Educational Technology, vol. 9(2), April 2010.

[8] Franco-Mariscal, A. J., Oliva-Martínez, J. M., \& Almoraima Gil, M. L., "Students' perceptions about the use of educational games as a tool for teaching the periodic table of elements at the high school level," Journal of Chemical Education, vol. 92(2), Oct 2015.

[9] Vanags, T., George, A. M., Diana, M. G. \& Brown P. M., "Bingo! An engaging activity for learning physiological terms in psychology," Teaching of Psychology, vol. 39(29), 2012.

[10] Miller, L. M., Chang, C. I., Wang, S., Beier, M. E., \& Klisch, Y., "Learning and motivational impacts of a multimedia science game," Computers \& Education, vol. 57(1), 2011.

[11] Yıldız, E., Şimşek, Ü., \& Ağdaş, H., "Effect of educational game integrated cooperative learning model on students' science learning motivation and social skills (in Turkey)," Journal of Kirsehir Education Faculty, vol. 18(2), pp. 37-54, 2017.

[12] Al-Tarawneh, M. H., "The effectiveness of educational games on scientific concepts acquisition in first grade students in science," Journal of Education and Practice, vol. 7(3), pp. 31-37, 2016.

[13] Bayır, E., Fazlığlu, Y. \& Günsen, G., "Teaching preschoolers science through play," Current Advances in Education, pp. 603-616, 2016.

[14] Zhang, X., "Acid-base poker: A card game introducing the concepts of acid and base at the college level," Journal of Chemical Education, vol. 94(5), 2017.

[15] Erlina, C. C., \& Dylan, P. W., "Prediction! The vsepr game: Using cards and molecular model building to actively enhance students' understanding of molecular geometry," Journal of Chemical Education, vol. 95(6), 2018.

[16] Costa, M. J.,"CARBOHYDECK: A card game to teach the stereochemistry of carbohydrates," Journal of Chemical Education, vol. 84(6), p. 977, 2007.

[17] Capps, K., "Chemistry taboo: an active learning game for the general chemistry classroom," Journal of Chemical Education, vol. 85(4), p. 518, 2008.

[18] Bayır, E., \& Deniz, C., "Designing a chemistry game and examining reflections about it," Journal of Science. Education. vol. 14, pp. 92-93, 2013.

[19] Morris, T. A., "Go chemistry: A card game to help students learn chemical formulas," Journal of Chemical Education, vol. 88(10), pp. 1397-1399, 2011

[20] Carin, A. A. \& Bass, J. E., "Teaching science as inquiry," Ninth edition, Upper Saddle River, NJ: PrenticeHall.

[21] Huppert, J., Lomask, S. M., \& Lazarowitz, R., "Computer simulations in the high school: Students'cognitive stages, science process skills and academic achievement in microbiology," International Journal of Science Education, vol. 24(8), pp. 803-821, 2002.

[22] Harlen, W., "Effective Teaching of Science. A Review of Research," Edinburgh: Scottish Council for Research in Education, 1999.

[23] Salgut, B., "The effect of computer aided instruction using internet in the light and sound unit of primary school 5th grade science and technology course on student success (in Turkey)," Master Thesis, Çukurova Üniversitesi/Sosyal Bilimler Enstitüsü, Adana, 2007. 
[24] Yücel, T., "Science and technology course learning strategies used in the solution of electric unit problems in our lives (in Turkey)," Master Thesis, Ahi Evran Üniversitesi/Sosyal Bilimler Enstitüsü, Kırşehir, 2012.

[25] Başdağ, G. \& Güneş, B., "The comparison of scientific process skills of 5th grade students studying in 2000 science and technology and 2004 science and technology course programs, (in Turkey)," VII. Ulusal Fen Bilimleri ve Matematik Ĕgitimi Kongresi, Gazi Üniversitesi, Ankara, 2006.

[26] Dumlu Güler, T., "6. Sinıf Fen ve Teknoloji Dersindeki 'Hücre Ve Organelleri" Konusunun Eğitsel Oyun Yöntemiyle Öğretilmesinin Öğrencilerin Akademik Başarısına Etkisi," Yüksek Lisans Tezi, Atatürk Üniversitesi/Eğitim Bilimleri Enstitüsü. Erzurum, 2011.

[27] Chang-Hung, L., Jian, F. Z., Tien-Li, L., Cheng-Wei, N., Chia, P. H., Pin-Hsuan, H., Hsiang-Ling, C., Shih-Yao, L. and Mei-Lin, H., "Using a table tennis game, "Elemental knock-out", to increase students' familiarity with chemical elements, symbols, and atomic numbers," Journal of Chemical Education, vol. 93(10), pp 1744-1748, 2016.

[28] Gürpınar, C., "The effect of educational games supported learning practices in science teaching on learning products (in Turkey)," Master Thesis, Kırıkkale Üniversitesi/Fen Bilimleri Enstitüsü, Kırıkkale, 2017.

[29] Öztürk Coşan, A., "The effect of scientific educational games on student achievement and retention in biology teaching (in Turkey)," Master Thesis, Gazi Üniversitesi/Eğitim Bilimleri Enstitüsü, Ankara, 2018.

[30] Ergul, R., Simsekli, Y., Calıs, S., Ozdilek, Z. \& Gocmencelebi, S., "The effects of inquiry-based science teaching on elementary school students' science process skills and science attitudes," Bulgarian Journal of Science and Education Policy, vol. 5(1), pp. 48-68, 2011.

[31] Sen, C. \& Sezen Vekli, G., "The Impact of Inquiry Based Instruction on Science Process Skills and Self-Efficacy Perceptions of Pre-Service Science Teachers at a University Level Biology Laboratory," Universal Journal of Educational Research, vol. 4(3), pp. 603-612, 2016.

[32] Şimşek, P. \& Kabapınar, F., "The effects of inquiry-based learning on elementary students' conceptual understanding of matter, scientific process skills and science attitudes," Procedia Social and Behavioral Sciences, vol. 2, pp. 1190-1194, 2010.

[33] Koksal, E.A. \& Berberoglu, G., "The Effect of Guided-Inquiry Instruction on 6th Grade Turkish Students' Achievement, Science Process Skills, and Attitudes toward Science," International Journal of Science Education, vol. 36(1), pp. 66-78, 2014.

\section{BIOGRAPHIES OF AUTHORS}

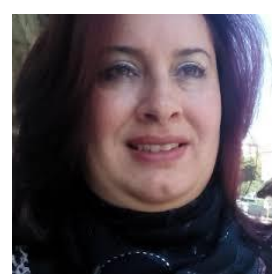

Dr. Eylem Bayır works at Trakya University, Turkey in the Science Education Department. Her interests include science teacher training, nature of science, the constructivist approach, inquirybased science learning, and educational games.

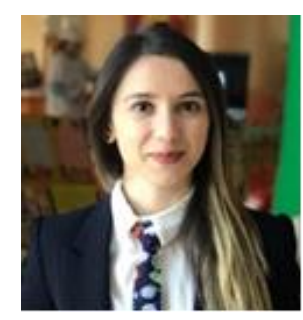

Sefanur Evmez is employed as science teacher at a state school in Turkey. Her MA was in the field of science education. Inquiry-based science learning and educational games are some of her research interests. 